\title{
ECONOMIC METHODS USED IN HEALTH TECHNOLOGY ASSESSMENT
}

\author{
Blanka Klímová, Petra Marešová
}

\section{Introduction}

Decision-making process about the development of new products is fundamental for the growth and prosperity of any company, particularly in the fast changing medical device market (Ivlev et al., 2015). Companies must innovate to be successful but this invariably carries some risk and uncertainty. In recent years, the issue of evaluation of investment effectiveness into medical devices has been intensively solved, both at national and international level (Heintz et al., 2016) due to the growing market with medical devices (Craig et al., 2014). Johal and Williams (2007) present three groups of decision making tools/techniques, which can help policy makers in the improvement of their early decisions on the development of a new product. These three groups of techniques consist of 1. strategic and financial valuation of projects (e.g., NPV, IRR, DCF), 2. weighting and scoring of products and product criteria (e.g., analytic hierarchy process (AHP) and conjoint analysis), 3. human decisionmaking (fuzzy logic, actuarial models, neural networks, technology road mapping and expert systems).

Currently, the most common and wellestablished method for the assessment of medical devices is health technology assessment (HTA). As Ciani et al. (2015) explain, HTA aims to provide policy makers with information on the clinical and economic value of health technologies (including pharmaceuticals, medical devices, clinical procedures, and organizational systems used in health care) in order to support their reimbursement or coverage decisions (Ivlev et al., 2014; Rosina et al., 2014; Rogalewicz, 2016). In fact, HTA plays the key role in informing reimbursement and pricing decisions and providing clinical guidance on the use of medical technologies across the world (Stephens, Handke, \& Dshi, 2012; Rogalewicz, Bartak, \& Kubatova, 2015).
One of the important methods of HTA is an economic evaluation which comprises a number of economic methods. The economic evaluation (EE) is a comparison of the costs and consequences of at least two choices (Drummond et al., 2005). With respect to new health technologies, EE compares the new health technology against the current standard-of-care treatment (Gavurova \& Soltes, 2016; Gavurova \& Vagasova, 2016). Sometimes, EE is called a cost-effectiveness analysis as it combines an analysis of costs and clinical effectiveness (EUPATI, 2017; Canadian Agency for Drugs and Technologies in Health, 2006; Rotter, Foerster, \& Bridges, 2012).

The EE processes are well-established in HTA of pharmaceuticals but not that much in the development of medical devices (Craig et al., 2014). The problem is that complete standardization of economic evaluations cannot be performed since the methods should be flexible enough to be compatible with different problems in different contexts (Mathes et al., 2013; Soltes \& Gavurova, 2015). In addition, as Rotter, Foerster, and Bridges (2012) argue, several different approaches can be potentially applied in decision modelling. Drummond, Griffin, and Tarricone (2009) in their study summarize the main reasons why assessments of devices differ from assessments of drugs, which are as follows:

- many devices are diagnostic; that is why the outcome cannot be separated from the treatment and, such devices have multiple applications;

- due to a short lifetime of devices, their frequent modifications, and the existence of "learning curves", there is unlikely to be a substantial steady-state period, during which the device could be evaluated in an $\mathrm{RCT}$;

- the effectiveness of a device depends both on the device itself and the way how 
it is used (e.g., the skill and experience of a doctor);

- introduction of a new treatment comprising a device may have wider economic implications;

- equivalent clinical evidence may not be available for all products, making comparisons difficult;

- prices may change in the course of time since new products penetrate the market, or because of the ways, in which purchasing is held.

The purpose of this review focuses on the exploration of the economic methods, commonly used in the economic evaluation as part of health technology assessment for medical devices. On the basis of the selected original studies, the authors summarize the main economic methods used in the decisionmaking processes about the development of new medical devices and discuss their benefits and limitations.

\section{Methods}

The methods included a method of literature search in the acknowledged databases for economic evaluations as suggested by Thielen et al. (2016). Search method followed the PRISMA guidelines for conducting systematic reviews (Moher et al., 2009). To ensure optimal coverage, additional articles were found within the reference section of retrieved articles and through citation snowballing by undertaking wider searches by author name for those appearing as key publishers in the area.

The databases thus were Web of Science, MEDLINE, and Embase. The authors searched relevant studies for the following key words: economic methods AND health technology assessment, economic methods AND HTA, economic evaluation AND health technology assessment, economic evaluation AND HTA, economic methods AND medical device AND health technology assessment.

The search period started in 2000 when the studies on the research topic started to appear and ends in December of 2016. Most of the articles were found in MEDLINE $(2,648)$, followed by Embase $(1,060)$, and Web of Science (986). In the last one, an increase in the number of articles on the research topic was the most obvious.

Articles that met the inclusion criteria of the quality of research papers were evaluated according to adequate description of the theoretical framework, background, and methodology (Mays \& Pope, 2000).

For those papers that fulfilled the criteria for quality, data was extracted according to the following content: date published, study funding source, possible conflicts of interest, study objectives, target population, application of tool, site/setting, study focus, HTA tool proposed or approach used in the paper, description of tool or approach, stand alone or support tool, aspects of clinical effectiveness, costs, and contextual issues, addressed by tool or approach, all stakeholders involved, literature search incorporated, results of implementation, and focus on medical technology/intervention.

Although the number of articles on the research topic is growing, most of the studies focused on the economic evaluations of pharmaceuticals and treatment. The inclusion criteria were as follows: the study was included if it were written in English, if it was original research study, not a review, if it covered the designated period, i.e., 2000-2016, and if it concerned the research topic, i.e., economic methods used in HTA for medical devices. In this review, the product is a medical device and it refers to a class II device (e.g., blood pressure monitors, contact lenses, pregnancy test kits, single-use surgical instruments, catheters), a class III device (e.g., ventilators, cardiac monitors, hip implants, knee implants, lasers, chlamydia test kits, glucose meters), or a class IV device (e.g., defibrillators, pacemakers, coronary stents, HIV test kits, neurosurgical shunts) that requires product licensing for general marketing purposes. The original research articles or clinical studies, however, were considered only back to the years of 2014-2016 since several review studies on this topic had been made before or even in this period, e.g., (Cooper et al., 2013; Craig et al., 2014; Markewicz, van Til, \& ljzerman, 2014; Mathes et al., 2013; Pham et al., 2014; Rotter, Foerster, \& Bridges, 2012; Stephens, Handke, \& Dshi, 2012).

Thus, after the identification of the relevant studies on the basis of their key words and their titles, the duplicated studies were excluded. Afterwards, the abstracts were screened and, eventually, only 39 remained for the full-text analysis, out of which 11 studies were then used for a detailed analysis of the economic methods. The findings from the selected studies are discussed and compared in the part on Discussion. 


\section{Findings}

The search retrieved 4,694 papers in total, out of which eleven fulfilled the inclusion criteria (PRISMA flowchart, Fig. 1). Data was extracted from the eleven papers published between 2000 and 2016.

Altogether 11 studies were identified according to the inclusion criteria described above. Nine studies were randomized controlled trials (Ashby et al., 2014; Downing et al., 2015; Harron et al., 2016; Lall et al., 2015; Murray et al., 2014; Rosenthal et al., 2015; Smulders et al., 2016; Walter et al., 2015), usually comparing clinical benefits and cost-effectiveness of the traditional device with a new developed one, one study was a prospective study (Dozet et al., 2016), using a cost-minimization analysis for societal impact reasons, and one was a survey (Heintz et al., 2016), conducted among 33 European countries, which are involved in the European
Network for Health Technology Assessment. The aim of this survey was to provide a general framework for economic evaluation at a European level. In the majority of the studies (9 studies) a cost-effectiveness was used. In some of these studies it was accompanied by a cost-utility analysis (3 studies), one study exclusively exploited the cost-utility analysis and one cost-minimization analysis. The studies are presented in alphabetical order of their first author. Consult Tab. 1 below.

\section{Discussion}

As the findings in Tab. 1 indicate, the most common economic method used in the economic evaluation of the medical device development is the cost-utility analysis (cf. Ashby et al., 2014; Downing et al., 2015; Heintz et al., 2016; Lall et al., 2015; Murray et al., 2014; Rosenthal et al., 2015; Smulders et al., 2016), followed by the cost-effectiveness analysis

\begin{tabular}{|c|c|c|c|}
\hline \multirow[t]{2}{*}{ Tab. 1: } & \multicolumn{3}{|c|}{$\begin{array}{l}\text { An overview of the studies focusing on the economic assessment of medical } \\
\text { devices }\end{array}$} \\
\hline & Study & Medical device & Economic method(s) used \\
\hline \multicolumn{2}{|c|}{$\begin{array}{l}\text { Ashby et al. (2014) } \\
\text { Randomized controlled trial } \\
\text { (RCT) }\end{array}$} & $\begin{array}{l}\text { Compression hosiery compared versus } \\
\text { compression bandaging }\end{array}$ & Cost-utility analysis \\
\hline \multicolumn{2}{|c|}{$\begin{array}{l}\text { Downing et al. (2015) } \\
\text { Cluster RCT }\end{array}$} & $\begin{array}{l}\begin{array}{l}\text { Non-pneumatic anti-shock garment first aid } \\
\text { device }\end{array} \\
\end{array}$ & Cost-utility analysis \\
\hline \multicolumn{2}{|c|}{$\begin{array}{l}\text { Dozet et al. (2016) } \\
\text { Prospective study }\end{array}$} & Mobile radiography technology & Cost-minimization analysis \\
\hline \multicolumn{2}{|c|}{$\begin{array}{l}\text { Featherstone et al. (2016) } \\
\text { RCT }\end{array}$} & $\begin{array}{l}\text { Carotid artery stenting versus carotid } \\
\text { endarterectomy }\end{array}$ & Cost-effectiveness analysis \\
\hline \multicolumn{2}{|c|}{$\begin{array}{l}\text { Harron et al. (2016) } \\
\text { RCT }\end{array}$} & $\begin{array}{l}\text { Impregnated central venous catheters } \\
\text { versus standard central venous catheters }\end{array}$ & Cost-effectiveness analysis \\
\hline \multicolumn{2}{|c|}{$\begin{array}{l}\text { Heintz et al. (2016) } \\
\text { Survey study }\end{array}$} & Different types of devices & $\begin{array}{l}\text { Cost-utility analysis, } \\
\text { cost-effectiveness analysis, } \\
\text { cost-minimization analysis, } \\
\text { cost-consequence analysis }\end{array}$ \\
\hline \multicolumn{2}{|c|}{$\begin{array}{l}\text { Lall et al. (2015) } \\
\text { RCT }\end{array}$} & $\begin{array}{l}\text { Conventional artificial ventilation versus } \\
\text { high/frequency oscillatory ventilation }\end{array}$ & Cost-utility analysis \\
\hline \multicolumn{2}{|c|}{$\begin{array}{l}\text { Murray et al. (2014) } \\
\text { RCT }\end{array}$} & Knee prostheses & Cost-utility analysis \\
\hline \multicolumn{2}{|c|}{$\begin{array}{l}\text { Rosenthal et al. (2015) } \\
\text { RCT }\end{array}$} & $\begin{array}{l}\text { Split-septum and single-use prefilled flushing } \\
\text { devices versus 3-way stopcock }\end{array}$ & Cost-utility analysis \\
\hline \multicolumn{2}{|c|}{$\begin{array}{l}\text { Smulders et al. (2016) } \\
\text { RCT }\end{array}$} & $\begin{array}{l}\text { Simultaneous bilateral cochlear implantation } \\
\text { versus unilateral cochlear implantation }\end{array}$ & Cost-utility analysis \\
\hline \multicolumn{2}{|c|}{$\begin{array}{l}\text { Walter et al. (2015) } \\
\text { RCT }\end{array}$} & Metal stents versus plastic stents & Cost-effectiveness analysis \\
\hline
\end{tabular}


(cf. Downing et al., 2015; Dozet et al., 2016; Heintz et al., 2016; Rosenthal et al., 2015), the cost-minimization analysis (cf. Dozet et al., 2016; Heintz et al., 2016), and the costconsequence analysis (cf. Heintz et al., 2016). These findings are in compliance with other research studies on this topic such as Brockis et al. (2006) or Mathes et al. (2013).

The cost-utility analysis (CUA) is mostly preferred and widely accepted because it enables a comparison between different indications and types of health technology, especially in state-funded health care systems. Its outcomes are measured as health-related preferences, described as Quality Adjusted Life Years (QALYs) gained. CUA is used when interventions can influence the health related quality of life and the length of life (Canadian Agency for Drugs and Technologies in Health, 2006). In addition, CUA aims at a higher level of standardization because the same denomination is used for all types of health technology and the methods to determine it can be better standardized (Mathes et al., 2013). As the survey study (Heintz et al., 2016) reveals, most European countries use CUA as the main type of economic analysis. CUA is considered to be better at providing a more complete analysis of total benefits than the cost-benefit analysis, which aims at estimating the strengths and weaknesses of alternatives (Gavurova \& Vagasova, 2016). However, CUA has certain limitations. As Penner (2017) states, it relies on estimates of QALYs (for further discussion of QALY in HTA Rogalewicz and Bartak (2017)) which may not be relevant for application in the CUA. Furthermore, there may be conflicting ideas about how to approach the assessment of human life and disability (Soltes \& Gavurova, 2015). Another problem seems to be the absence of incorporating the patient's willingness to pay in decisions to finance new treatments (NICE, 2013).

The second mentioned and commonly used economic method is the cost-effectiveness analysis (CEA), which could be implemented as a secondary analysis when the use of an important patient outcome measure (other than a QALY gained) could be justified if there is evidence of a meaningful difference in such an outcome compared with alternatives 8 . As Weintraub and Cohen (2009) claim, CEA is an approach that can be used to extend the understanding of efficacy data, which are frequently retrieved from RCTs. If it is relevantly applied, in some cases it may be more beneficial than comparisons of cost alone, sometimes called cost-minimization studies, which implicitly suggest equivalence of efficacy. There are also limitations of CEA in terms of methodological difficulties such as measurement. CEA results can be only compared with the results of other technologies that are expressed in the same outcome measure. In addition, there might be ethical issues about the low acceptance of valuing health in monetary units in some societies (Mathes et al., 2013). Both CEA and CUA are expressed as an incremental cost-effectiveness ratio (ICER), i.e., the ratio of change in costs to the change in effects (What is the incremental cost-effectiveness ratio (ICER, 2017).

The third method implemented in the studies in Tab. 1 is the cost-minimization analysis (CMA). This method focuses on measuring and comparing the costs of different medical interventions. Thus, for example, the Scottish Medicines Consortium (SMC) recommend the use of CMA for therapeutically equivalent treatments established through non-inferiority studies; indirect comparisons showing statistically insignificant difference; or where cost-utility analysis shows extremely small quality-adjusted life year differences between treatments, however, the comparators must be appropriate and effectiveness must be comparable (Marshall et al., 2015). The principal limitations of this cost evaluation method are that it can only be used to compare treatments that provide the same benefits or effectiveness (identical outcomes, e.g., therapeutic effects); moreover, costs need to be determined accurately. In this way, a decision maker can choose the treatment with the lowest total cost. The assessment of costs is performed by identifying the study's perspective, all the resources used, and quantifying them into physical units (Duemas, 2013).

The last method mentioned in Tab. 1 is the cost-consequence analysis (CCA), which provides disaggregated costs and a range of outcomes such as intervention costs, hospital costs, clinical benefits, and adverse effects (Drummond et al., 2005). It can be beneficial for illustrating the impact of the intervention and it can be used as intermediate step for another type of evaluation. On the contrary, CCA is demanding for aggregating, weighing, and valuing the components on the user of the study 
(Canadian Agency for Drugs and Technologies in Health, 2006).

Apart from the methods discussed in Tab. 1, other economic methods are sometimes used, for example, the cost-benefit analysis or the Headroom Method. The cost-benefit analysis (CBA) values costs and outcomes in monetary terms. In this method all direct and indirect costs of health care are included as well as economic valuations of the outcomes. However, only economic distinctions are made between the value to society or individuals of having particular health outcomes. That is why there are ethical issues connected with assigning monetary values to health outcomes (Sinkey \& Odibo, 2016).
The Headroom Method is especially important in the early assessment of the medical device since it can reveal whether the device will be commercially viable in the healthcare market. This is usually done by estimating the maximum reimbursable price (MRP) for a new device idea, and comparing this reimbursement opportunity with a developer's expected costs (Chapman, Taylor, \& Girling, 2013; Girling et al., 2015).

Overall, as this study and other research studies indicate, CUA and CEA are preferred methods in the economic evaluations. As Mathes et al. (2013) suggest the comparator should be usual care. They recommend discounting rates range from $1.5-5 \%$ for effects

\section{Tab. 2: Comparison of methods - Part 1}

\begin{tabular}{|c|c|c|c|c|}
\hline & Aim of the method & $\begin{array}{l}\text { Conditions for } \\
\text { applying the ana- } \\
\text { lysis }\end{array}$ & Benefits & Limitations \\
\hline CBA & $\begin{array}{l}\text { Facilitate efficient } \\
\text { allocation of social } \\
\text { resources. }\end{array}$ & $\begin{array}{l}\text { Costs and benefits } \\
\text { are identified and } \\
\text { judged from the } \\
\text { perspective of the } \\
\text { company. }\end{array}$ & $\begin{array}{l}\text { It expresses the } \\
\text { degree of benefit of } \\
\text { the program, while } \\
\text { quantifying the } \\
\text { benefits of monetary } \\
\text { indicators. It is } \\
\text { possible to compare } \\
\text { procedures with } \\
\text { different types of } \\
\text { outcomes. }\end{array}$ & $\begin{array}{l}\text { Quantification } \\
\text { is expressed in } \\
\text { monetary units, } \\
\text { these statements } \\
\text { are inaccurate, plus } \\
\text { ethical issues. }\end{array}$ \\
\hline CEA & $\begin{array}{l}\text { Compare the costs } \\
\text { of varied medical } \\
\text { procedures in relation } \\
\text { to improving the } \\
\text { patient's condition. }\end{array}$ & $\begin{array}{l}\text { Costs are measured } \\
\text { against the measure } \\
\text { of the effect that } \\
\text { is not expressed } \\
\text { in monetary units. } \\
\text { Natural and physical } \\
\text { units are indicators of } \\
\text { program implications. }\end{array}$ & $\begin{array}{l}\text { Comparison of } \\
\text { costs and outputs, } \\
\text { quantification of } \\
\text { outputs. }\end{array}$ & $\begin{array}{l}\text { In most cases, it only } \\
\text { takes into account the } \\
\text { direct costs, suitable } \\
\text { for comparison within } \\
\text { a group. }\end{array}$ \\
\hline CUA & $\begin{array}{l}\text { Assess treatment } \\
\text { practices that } \\
\text { only extend the } \\
\text { prolongation of human } \\
\text { life to the cost of side } \\
\text { effects. }\end{array}$ & $\begin{array}{l}\text { It compares the } \\
\text { cost of one variable. } \\
\text { Consequences are } \\
\text { measured in natural } \\
\text { units. }\end{array}$ & $\begin{array}{l}\text { It accumulates two } \\
\text { aspects: 1) the length } \\
\text { of life that is obtained } \\
\text { through the treatment; } \\
\text { 2) improving the } \\
\text { quality of life. }\end{array}$ & $\begin{array}{l}\text { The outputs are } \\
\text { measured by the } \\
\text { QALY method. }\end{array}$ \\
\hline CMA & $\begin{array}{l}\text { Find a treatment } \\
\text { procedure whose } \\
\text { costs are the lowest. }\end{array}$ & $\begin{array}{l}\text { For identical results } \\
\text { achieved by reciprocal } \\
\text { treatment. }\end{array}$ & $\begin{array}{l}\text { It is the simplest of } \\
\text { the one-criterion cost- } \\
\text { output methods. }\end{array}$ & $\begin{array}{l}\text { Only to compare costs } \\
\text { and not the outputs. } \\
\text { Procedures must } \\
\text { be of comparable } \\
\text { effectiveness - the } \\
\text { same outcomes. }\end{array}$ \\
\hline
\end{tabular}




Tab. 2: Comparison of methods - Part 2
\begin{tabular}{l|l|l|l|l} 
ICER & $\begin{array}{l}\text { Show how much more } \\
\text { funds are needed to } \\
\text { achieve additional } \\
\text { therapeutic benefit. }\end{array}$ & $\begin{array}{l}\text { It is the ratio of cost } \\
\text { differences and } \\
\text { efficiency. }\end{array}$ & Use for CEA. & None. \\
\hline QALY & $\begin{array}{l}\text { Determine which } \\
\text { treatment will bring } \\
\text { one year of life to } \\
\text { the highest possible } \\
\text { quality at the lowest } \\
\text { possible price. }\end{array}$ & $\begin{array}{l}\text { It assesses: } \\
\text { 1) physical status and } \\
\text { functions, } \\
\text { 2) mental state and } \\
\text { mental functions, } \\
\text { 3) social ties, } \\
\text { 4) economic status } \\
\text { and occupation. }\end{array}$ & $\begin{array}{l}\text { Simplicity, clarity } \\
\text { for many actors: we } \\
\text { get a single number } \\
\text { that can be easily } \\
\text { interpreted. }\end{array}$ & $\begin{array}{l}\text { Various tools for } \\
\text { measuring quality } \\
\text { of life, which } \\
\text { often provide } \\
\text { conflicting results. } \\
\text { Methodological } \\
\text { problems of individual } \\
\text { questionnaires } \\
\text { and ways of their } \\
\text { evaluation. }\end{array}$ \\
\hline
\end{tabular}

Source: own

and $3-5 \%$ for costs although it is desirable to use the same rate for costs and effects. In addition, the recently developed Headroom Method is recommended to be used in the early assessment of the medical device development since it uses broader estimates of potential by determining the maximum reimbursable price of the new device. In fact, it is tailored to the early assessment needs of medical device (Mays \& Pope, 2000), which is essential in the manufacturers' decision-making process and other potential stakeholders.

Fig. 1 below illustrates a possible hierarchical implementation model of the economic methods used in the economic evaluations of the medical device development.

\section{Fig. 1: An overview of the recommended economic methods for the economic evaluations of the medical device development}

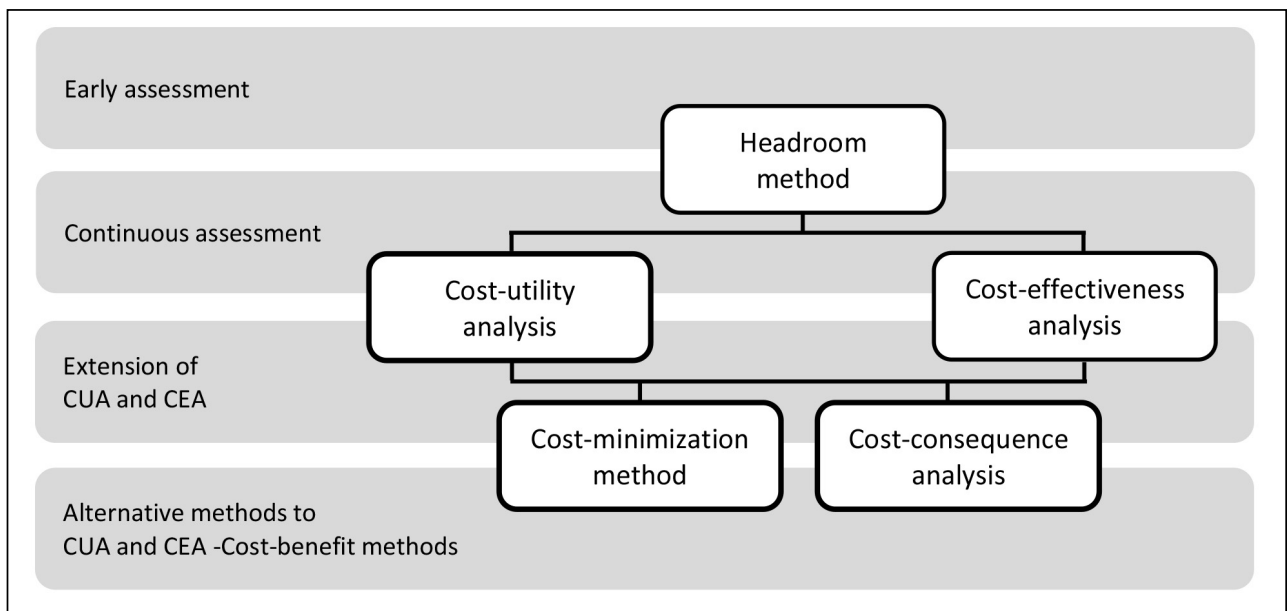




\section{Conclusions}

As the findings of this study show, there are several methods of economic evaluation whose selection depends on the research question, the condition of interest, and the availability of data on outcomes.

In comparison with the obtained results, the CEA, CMA, CUA, ICER and QALY methods are used in the Czech Republic for cost effectiveness evaluation.

A cost-effective procedure is then a procedure which, at comparable costs, brings about the same or higher therapeutic effect of extending life, improving the quality of life, or improving the essential measurable criterion of the disease in question. Or a tactical procedure which, with at least a comparable therapeutic effect, means lower overall costs for the health insurance system (Section 15 (8) of the Public Health Insurance Act).

As in other areas of health care (Maresova, Klimova, \& Kuca, 2015; Maresova et al., 2015a,b; Maresova et al., 2016) there is an urgent need to conduct the early assessment of the medical device development in order to avoid negatively high costs and prevent a failure rate at each stage of the development process.

This study was supported by the research project The Czech Science Foundation (GACR) 2017 No. 17-03037S Investment evaluation of medical device development, run at the Faculty of Informatics and Management, University of Hradec Kralove, Czech Republic.

\section{References}

Ashby, R. L., Gabe, R., Ali, S., et al. (2014). VenUS IV (Venous Leg Ulcer Study IV) - Compression Hosiery Compared with Compression Bandaging in the Treatment of Venous Leg Ulcers: A Randomised Controlled Trial, Mixed-Treatment Comparison and Decision-Analytic Model. Health Technology Assessment, 18(57), 1-293. https://dx.doi. org/10.3310/hta18570.

Brockis, E., Marsden, G., Cole, A. et al. (2006). A Review of NICE Methods across Health Technology Assessment Programmes: Differences, Justifications and Implications (Research Paper 16/03). Office of Health Economics. Retrieved from https://www.ohe. org/publications/review-nice-methods-across- health-technology-assessment-programmesdifferences\#.

Canadian Agency for Drugs and Technologies in Health. (2006). Guidelines for the economic evaluation of health technologies: Canada. Retrieved July, 9, 2017, from http:// www.inahta.org/wp-content/themes/inahta/img/ AboutHTA_Guidelines_for_the_Economic_ Evaluation_of_Health_Technologies.pdf.

Ciani, O., Wilcher, B., Blankart, C. R. et al. (2015). Health Technology Assessment of Medical Devices: A Survey of Non-European Union Agencies. International Journal of Technology Assessment in Health Care, 31(3), 154-165. https://dx.doi.org/10.1017/ S0266462315000185.

Chapman, A. M., Taylor, C. A., \& Girling, A. J. (2013). Early HTA to Inform Medical Device Development Decisions - the Headroom Method. In R. L. Roa (Ed.), XIII Mediterranean Conference on Medical and Biological Engineering and Computing 2013. IFMBE Proceedings, vol 41 (pp. 1151-1154). Springer, Cham. https://dx.doi. org/10.1007/978-3-319-00846-2_285.

Cooper, N. J., Spiegelhalter, D., Bujkiewicz, S. et al. (2013). Use of Implicit and Explicit Bayesian Methods in Health Technology Assessment. International Journal of Technology Assessment in Health Care, 29(3), 336-342. https://dx.doi.org/10.1017/ S0266462313000354.

Craig, J., Carr, Z., Hutten, J. et al. (2014). A Review of the Economic Tools for Assessing New Medical Devices. Appl Health Econ Health Policy, 13(1), 15-27. https://dx.doi.org/10.1007/ s40258-014-0123-8.

Downing, J., El Ayadi, A., Miller, S. et al. (2015). Cost-Effectiveness of the NonPneumatic Anti-Shock Garment (NASG): Evidence from a Cluster Randomized Controlled Trial in Zambia and Zimbabwe. BMC Health Serv Res, 15(37). https://dx.doi.org/10.1186/ s12913-015-0694-6.

Dozet, A., Ivarsson, B., Eklund, K. et al. (2016). Radiography on Wheels Arrives to Nursing Homes - An Economic Assessment of a New Health Care Technology in Southern Sweden. Journal of Evaluation in Clinical Practice, 22(6), 990-997. https://dx.doi. org/10.1111/jep.12590.

Drummond, M., Sculpher, M., Torrance, G. et al. (2005). Methods for the Economic Evaluation of Health Care Programmes. Oxford: OUP. 
Drummond, M., Griffin, A., \& Tarricone, R. (2009). Economic Evaluation for Devices and Drugs, Same or Different? Value in Health, 12(4), 402-404. https://dx.doi.org/10.1111/ j.1524-4733.2008.00476_1.x.

Duenas, A. (2013). Cost-Minimization Analysis. In M. D. Gellman, \& J. R. Turner (Eds.), Encyclopedia of Behavioral Medicine (pp. 513). New York: Springer.

EUPATI. (2017). Economic evaluation in HTA. Retrieved July, 9, 2017, from https://www.eupati.eu/health-technologyassessment/economic-evaluation-in-hta/.

Featherstone, R. C., Dobson, J., Ederle, J. et al. (2016). Carotid Artery Stenting Compared with Endarterectomy in Patients with Symptomatic Carotid Stenosis (International Carotid Stenting Study): A Randomised Controlled Trial with Cost-Effectiveness Analysis. Health Technol Assess, 20(20), 1-94. https://dx.doi.org/10.3310/hta20200.

Gavurova, B., \& Soltes, M. (2016). System of day surgery in Slovakia: analysis of pediatric day surgery discrepancies in the regions and their importance in strategy of its development. E\&M Ekonomie a Management, 19(1), 74-92. https://doi.org/10.15240/tul/001/2016-1-006.

Gavurova, B., \& Vagasova, T. (2016). Regional differences of standardised mortality rates for ischemic heart diseases in the Slovak Republic for the period 1996-2013 in the context of income inequality. Health Economics Review, 6(21). https://dx.doi.org/10.1186/ s13561-016-0099-1.

Girling, A., Lilford, R., Cole, A. et al. (2015). Headroom Approach to Device Development: Current and Future Directions. International Journal of Technology Assessment in Health Care, 31(5), 331-338. https://dx.doi. org/10.1017/S0266462315000501.

Harron, K., Mok, Q., Dwan, K. et al. (2016). CATheter Infections in CHildren (CATCH): A Randomised Controlled Trial and Economic Evaluation Comparing Impregnated and Standard Central Venous Catheters in Children. Health Technol Assess, 20(18), 1-219. https://dx.doi.org/10.3310/hta20180.

Heintz, E., Gerber-Grote, A., Ghabri, S. et al. (2016). Is There a European View on Health Economic Evaluations? Results from a Synopsis of Methodological Guidelines Used in the EUnetHTA Partner Countries. PharmacoEconomics, 34(1), 59-76. https://dx.doi.org/10.1007/s40273-015-0328-1.
Ivlev, I., Kneppo, P., \& Barták, M. (2015). Method for selecting expert groups and determining the importance of experts' judgments for the purpose of managerial decision-making tasks in health system. E\&M Ekonomie a Management, 18(2), 57-72. https://doi.org/10.15240/tul/001/2015-2-005.

Ivlev, I., Kneppo, P., \& Bartak, M. (2014). Multicriteria decision analysis: a multifaceted approach to medical equipment management. Technological and Economic Development of Economy, 20(3), 576-589. https://doi.org10.3846/20294913.2014.943333.

Johal, S., \& Williams, H. (2007). Decisionmaking tools for medical device development. Retrieved July, 9, 2017, from http://www. nottingham.ac.uk/match/Publications/johal_ ABHI_focus_magazine_march_2007.pdf.

Küca, K., Soukup, O., Maresova, P. et al. (2016). Current Approaches againstAlzheimer's Disease in Clinical Trials. J Med Chem, 27, 641-649. http://dx.doi.org/10.5935/01035053.20160048.

Lall, R., Hamilton, P., Young, D. et al. (2015). A Randomized Controlled Trial and Cost-Effectiveness Analysis of HighFrequency Oscillatory Ventilation against Conventional Artificial Ventilation for Adults with Acute Respiratory Distress Syndrome. The OSCAR (OSCillation in ARDS) Study. Health Technol Assess, 19(23), 1-177. https://dx.doi. org/10.3310/hta19230.

Maresova, P., Klimova, B., Novotny, M. et al. (2016). Alzheimer's and Parkinson's Diseases: Expected Economic Impact on Europe-A Call for a Uniform European Strategy. J Alzheimers Dis, 54(3), 1123-1133. https://dx.doi.org/10.3233/JAD-160484.

Maresova, P., Klimova, B., \& Kuca, K. (2015). Alzheimer's Disease: Cost Cuts Call for Novel Drugs Development and National Strategy. Česká a slovenská farmacie, 64, 25-30.

Maresova, P., Klimova, B., Krejcar, O. et al. (2015a). Legislative Aspects of the Development of Medical Devices. Česká a slovenská farmacie, 64, 133-138.

Maresova, P., Mohelska, H., Dolejs, J., \& Kuca, K. (2015b). Socio-economic Aspects of Alzheimer's Disease. Current Alzheimer Research, 12(9), 903-911. https://dx.doi.org/10. 2174/156720501209151019111448.

Markewicz, K., van Til, J. A., \& ljzerman, M. J. (2014). Medical Devices Early Assessment 
Methods: Systematic Literature Review. International Journal of Technology Assessment in Health Care, 30(2), 137-146. https://dx.doi. org/10.1017/S0266462314000026.

Marshall, J. D., Harries, M., Hill, D. et al. (2015). Trends in the Use of Cost-Minimization Analysis in Economic Assessments Submitted to the SMC. Value in Health, 18(3), A94. https://dx.doi.org/10.1016/j.jval.2015.03.549.

Mathes, T., Jacobs, E., Morfeld, J. C. et al. (2013). Methods of International Health Technology Assessment Agencies for Economic Evaluations - A Comparative Analysis. BMC Health Services Research, 13(371). https://dx.doi.org/10.1186/1472-6963-13-371.

Mays, N., \& Pope, C. (2000). Qualitative Research in Health Care. Assessing Quality in Qualitative Research. BMJ, 320(7226), 50-52.

Moher, D., Liberati, A., Tetzlaff, J., Altman, D. G., \& The PRISMA Group. (2009). Preferred Reporting Items for Systematic Reviews and Meta-Analyses: The PRISMA Statement. PLoS Medicine, 6(7), 1-6. https://doi.org/10.1371/ journal.pmed.1000097.

Murray, D. W., MacLennan, G. S., Breeman, S. et al. (2014). A Randomised Controlled Trial of the Clinical Effectiveness and CostEffectiveness of Different Knee Prostheses: the Knee Arthroplasty Trial (KAT). Health Technol Assess, 18(19), 1-235. https://dx.doi. org/10.3310/hta18190.

National Institute for Health and Care Excellence [NICE]. (2013). Guide to the methods of technology appraisal 2013. London: NICE.

Penner, S. J. (2017). Economics and Financial Management for Nurses and Nurse Leaders. New York: Springer.

Pham, B., Tu, H.A. T., Han, D., Pechlivanoglou, P. et al. (2014). Early Economic Evaluation of Emerging Health Technologies: Protocol of a Systematic Review. Systematic Reviews, 3(81). https://dx.doi.org/10.1186/2046-4053-3-81.

Rogalewicz, V., Barták, M., \& Kubátová, I. (2015). Quality and Availability of Cost data in Czech HTA Research. In CEFE 2015 Central European Conference in Finance and Economics. Košice: TU Košice.

Rogalewicz, V., \& Barták, M. (2017). Kontroverze okolo QALY. Vnitřní lékařství, (4). Retrieved from http://www.vnitrnilekarstvi.eu/ vnitrni-lekarstvi.

Rosenthal, V. D., Udwadia, F. E., Kumar, S. et al. (2015). Clinical Impact and Cost-
Effectiveness of Split-Septum and Single-Use Prefilled Flushing Device vs 3-Way Stopcock on Central-Associated Bloodstream Infection Rates in India: A Randomized Clinical Trial Conducted by the International Nesoconial Infection Control Consortium (INICC). American Journal of Infection Control, 43(10), 1040-1045. https://dx.doi.org/10.1016/j.ajic.2015.05.042.

Rosina, J., Rogalewicz, V., Ivlev, I. et al. (2014). Health Technology Assessment for Medical Devices. Lekar a technika - Clinician and Technology, 44(3), 23-36.

Soltes, M., \& Gavurova, B. (2015). Quantification and Comparison of Avoidable Mortality - Causal Relations and Modification of Concepts. Technological and Economic Development of Economy, 21(6), 917-938. https://dx.doi.org/10.3846/20294913.2015.110 6421.

Rotter, J. S., Foerster, D., \& Bridges, J. F. (2012). The Changing Role of Economic Evaluation in Valuing Medical Technologies. Expert Rev Pharmacoecon Outcomes Res, 12(6), 711-723. https://dx.doi.org/10.1586/ erp.12.73.

Sinkey, R. G., \& Odibo, A. (2016). CostEffectiveness of Old and New Technologies for Aneuploidy Screening. Clin Lab Med, 36(2), 237-248. https://dx.doi.org/10.1016/j. cll.2016.01.008.

Stephens, J. M., Handke, B., \& Dshi, J. A. (2012). International Survey of Methods Used in Health Technology Assessment (HTA): Does Practice Meet the Principles Proposed for Good Research? Comparative Effectiveness Research, (2), 29-44. https:// dx.doi.org/10.2147/CER.S22984.

Smulders, Y. E., van Zon, A., Stegeman, I. et al. (2016). Cost-Utility of Bilateral versus Unilateral Cochlear Implantation in Adults: A Randomized Controlled Trial. Otol Neurotol, 37(1), 38-45. https://dx.doi.org/10.1097/ MAO.0000000000000901.

Thieken, F. W., Van Mastrigt, G. A. P. G., Burgers, L. T. et al. (2016). How to Prepare a Systematic Review of Economic Evaluations for Clinical Practice Guidelines: Database Selection and Search Strategy Development (part 2/3). Expert Review of Pharmacoeconomics \& Outcomes Research, 16(6), 705-721. https://dx.doi.org/10.1080/147 37167.2016.1246962.

Walter, D., van Boeckel, P. G., Groenen, M. J. et al. (2015). Cost Efficacy of Metal 
Stents for Facilliation of Extrahepatic Bill Duct Obstruction in a Randomized Controlled Trial. Gastroenterology, 149(1), 130-138. https:// dx.doi.org/10.1053/j.gastro.2015.03.012.

Weintraub, W., \& Cohen, D. (2009). The Limits of Cost-Effectiveness Analysis. Cardiovascular Perspectives, 2(1), 55-58. https://dx.doi. org/10.1161/CIRCOUTCOMES.108.812321. doc. PhDr. Blanka Klímová, M.A., Ph.D.

University of Hradec Králové

Faculty of Informatics and Management Department of Applied Linguistics Czech Republic blanka.klimova@uhk.cz

doc. Mgr. Ing. Petra Marešová, Ph.D. University of Hradec Králové

Faculty of Informatics and Management Department of Economics Czech Republic petra.maresova@uhk.cz 


\section{Abstract}

\section{ECONOMIC METHODS USED IN HEALTH TECHNOLOGY ASSESSMENT}

\section{Blanka Klímová, Petra Marešová}

Early decision-making process about the development of a new product is essential for any company in order to gain relevant financial returns and thus prosper. Therefore, managers need to have at their disposal appropriate assessment tools which assist them in their decisions about the development of the new product and guarantee that their product will generate a desirable profit. The purpose of this review focuses on the exploration of the methodology, commonly used in the economic evaluation as part of health technology assessment for medical devices. On the basis of the selected original studies, the authors summarize the main methods used in the decision-making processes about the development of new medical devices and discuss their benefits and limitations. The methods employed in this study include a method of literature search in the databases Web of Science, MEDLINE, and Embase, and a method of comparison and evaluation of the results. The findings of this study indicate that the most preferred methods used in the economic evaluations of medical device development are cost-utility analysis and cost-effectiveness analysis. In addition, the Headroom Method is recommended to be used in the early assessment of the medical device development since it uses broader estimates of potential by determining the maximum reimbursable price of the new device. Selection of each method then depends on the research question, the condition of interest, and the availability of data on outcomes. There is an urgent need to conduct the early assessment of the medical device development in order to avoid negatively high costs and prevent a failure rate at each stage of the development process.

Key Words: Economic evaluation, methodology, health technology assessment, review.

JEL Classification: 115, M10.

DOI: 10.15240/tul/001/2018-1-008 